\title{
Melatonin Improves Parthenogenetic Development of Vitrified-Warmed Mouse Oocytes Potentially by Promoting G1/S Cell Cycle Progression
}

\author{
Bo Pan ${ }^{1,{ }^{\dagger}}$, Haoxuan Yang ${ }^{1,{ }^{\dagger}}$, Zhenzheng $\mathrm{Wu}^{1}{ }^{1}$, Izhar Hyder Qazi ${ }^{1,2}{ }^{\oplus}$, Guoshi Liu ${ }^{3}$, \\ Hongbing Han ${ }^{3}$, Qingyong Meng ${ }^{4}$ and Guangbin Zhou ${ }^{1, *(1)}$ \\ 1 Farm Animal Genetic Resources Exploration and Innovation Key Laboratory of Sichuan Province, \\ College of Animal Science and Technology, Sichuan Agricultural University, Chengdu-611130, China; \\ bopan1992@163.com (B.P.); yanghaoxuan940712@gmail.com (H.Y.); WZZ15680826096@163.com (Z.W.); \\ vetdr_izhar@yahoo.com (I.H.Q.) \\ 2 Department of Veterinary Anatomy \& Histology, Shaheed Benazir Bhutto University of Veterinary and \\ Animal Sciences, Sakrand-67210, Sindh, Pakistan \\ 3 National Engineering Laboratory for Animal Breeding, Key Laboratory of Animal Genetics and Breeding of \\ the Ministry of Agriculture, Beijing Key Laboratory for Animal Genetic Improvement, College of Animal \\ Science and Technology, China Agricultural University, Beijing 100193, China; gshliu@cau.edu (G.L.); \\ hanhongbing@cau.edu.cn (H.H.) \\ 4 State Key Laboratory of AgroBiotechnology, China Agricultural University, Beijing 100193, China; \\ qymeng@cau.edu.cn \\ * Correspondence: zguangbin@sicau.edu.cn; Tel.: +86-159-081-89189 \\ + These authors contributed equally to this work.
}

Received: 13 November 2018; Accepted: 10 December 2018; Published: 13 December 2018

\begin{abstract}
This study aimed to investigate the effect of melatonin on the cell cycle of parthenogenetic embryos derived from vitrified mouse metaphase II (MII) oocytes. Fresh oocytes were randomly allocated into three groups: untreated (control), or vitrified by the open-pulled straw method without (Vitrification group) or with melatonin (MT) supplementation (Vitrification + MT group). After warming, oocytes were parthenogenetically activated and cultured in vitro, then the percentage of embryos in the G1/S phase, the levels of reactive oxygen species (ROS) and glutathione (GSH), and the mRNA expression of cell cycle-related genes (P53, P21 and E2F1) in zygotes and their subsequent developmental potential in vitro were evaluated. The results showed that the vitrification/warming procedures significantly decreased the frequency of the $S$ phase, markedly increased ROS and GSH levels and the expression of P53 and P21 genes, and decreased E2F1 expression in zygotes at the G1 stage and their subsequent development into 2-cell and blastocyst stage embryos. However, when $10^{-9} \mathrm{~mol} / \mathrm{L}$ MT was administered for the whole duration of the experiment, the frequency of the $S$ phase in zygotes was significantly increased, while the other indicators were also significantly improved and almost recovered to the normal levels shown in the control. Thus, MT might promote G1-to-S progression via regulation of ROS, GSH and cell cycle-related genes, potentially increasing the parthenogenetic development ability of vitrified-warmed mouse oocytes.
\end{abstract}

Keywords: melatonin; oocyte vitrification; redox homeostasis; cell cycle; developmental potential; mouse

\section{Introduction}

Oocyte cryopreservation, an adjunct to artificial assisted reproductive technologies, has been widely applied in the fields of medicine, agriculture and scientific research [1-4]. Especially in the 
medical field, it has provided the means for women suffering from ovarian cancer [5] or premature ovarian failure [6] and those planning to delay pregnancy [7] to reach their goals of having a baby. Moreover, it also has offered a convenient way to protect endangered wildlife germplasm resources [8] and to build superior breeding pools for livestock $[9,10]$. However, the survival rate of oocytes and their subsequent developmental competence are decreased significantly after vitrification when compared with these characteristics of fresh oocytes [11-13]. The decreased developmental potential due to oocyte cryopreservation may inevitably result from the alteration of intracellular levels of reactive oxygen species (ROS) [14] or glutathione (GSH) [15], and/or gene expression [16-18].

Reactive oxygen species, generated as a part of normal cellular metabolism, are essential for cell signal transduction $[19,20]$. At moderate levels, ROS produce beneficial effects on cellular responses and function. However, at higher concentrations, they can lead to severe detrimental effects such as DNA damage, lipid peroxidation and protein oxidation [21-23]. Glutathione, a small peptide molecule composed of only three amino acids, acts as an effective antioxidant and free radical scavenger and plays a key role in regulating cellular redox homeostasis [24]. Therefore, ROS and GSH are pivotal to maintaining the level of reductants and oxidants in a balanced state [25] in order to regulate oocyte maturation and normal development of zygotes. After oocytes are subjected to vitrification and warming, ROS levels are generally increased $[13,14]$ and, conversely, GSH levels tend to decline $[15,26,27]$. In such situations, redox homeostasis would be perturbed, potentially weakening the quality of oocytes and reducing their developmental competence [28]. Moreover, under conditions of increased ROS levels, cell cycle progression during the in vitro development of mammalian oocytes and embryos is thought to be delayed or arrested [29,30]. Therefore, taking the foregoing facts into consideration, it is worthwhile to further elucidate how ROS and GSH levels are altered when oocytes are subjected to the vigorous procedures of cryopreservation and whether these induced changes affect the transition of cell cycle progression in parthenogenetic zygotes derived from vitrified-warmed mouse oocytes.

Similarly, the mRNA expression of stress-related genes (Hsp70, Sod1) [31,32], antioxidant genes (MnSOD, CuSOD) [33] and apoptosis-related genes (P53, BCL2, BAX) [34,35] would be altered after oocytes or embryos are subjected to vitrification-warming procedures. However, there is a comparative dearth of scientific evidence reporting potential impacts of the vigorous preconditions of cryopreservation on mRNA expression of cell cycle-related genes (P53, P21 and E2F1). P53 and $P 21$ are core genes of cell cycle checkpoints and play a major role in maintaining cell cycle arrest [36,37]. In human cancer cells, G1 arrest was completely abrogated when P21 was deficient [38], and P53 expression overcame P21WAF1/CIP1-mediated G1 arrest and induced apoptosis [39]. E2F1 works as a transcription factor and is closely related to the G1/S transition and DNA synthesis [40]. Under conditions of reduced mRNA expression and reduced or inhibited activity of E2F1, essential components required for DNA replication are also substantially reduced and may lead to deficient or complete arrest in the G1/S transition [41,42]. Therefore, in view of the paucity of relevant reports on this particular topic, much remains to be elucidated. Hence, it is reasonable to study and explore whether the decrease in developmental competence of vitrified-warmed mouse oocytes is related to changes in the expression of cell cycle-related genes (P53, P21 and E2F1) of the G1 phase.

Melatonin (MT), a scavenger of ROS, can promote oocyte maturation in vitro and enhance the rate of blastocyst formation of embryos cultured in vitro [43-45]. In this regard, in our previous study, we reported that $10^{-9} \mathrm{~mol} / \mathrm{L}$ MT supplementation during vitrification/warming, activation and in vitro culture could increase the development potential of vitrified-warmed mouse metaphase II (MII) oocytes [13]. Meanwhile, previously MT was found to play an important role in cancer treatment. It could inhibit the proliferation of oncocytes by regulating cell cycle arrest and apoptosis [46]. Currently, it is largely unclear whether MT promotes the development potential of vitrified-warmed mouse oocytes by regulating redox homeostasis and cell cycle progression.

The mouse has been regarded as a robust model for studying the mammalian embryonic development. Moreover, the extensive genome similarities between mouse and human being along 
with the experimental tractability of the mouse also furnish significant benefits to using this species. Moreover, mouse oocytes and embryos are also more readily available compared to those of other agriculturally-important livestock species [47]. Due to the practical, ethical and legal limitations, it is relatively difficult to use a human model of oocyte cryopreservation and embryo development in vitro in experimental studies requiring a higher number of oocytes and embryos. Thus, in the present study, we used a mouse model to elucidate the potential underlying mechanism of MT in promoting development of vitrified-warmed mouse oocytes in vitro by regulating cell cycle progression, cell cycle-related genes and redox homeostasis of parthenogenetic zygotes.

\section{Results}

\subsection{Melatonin Promotes the G1/S Transition of Parthenogenetic Zygotes Derived from Vitrified Mouse Oocytes}

As shown in Figure 1A, a space was observed between two pronuclei and no nucleolus was evident in mouse zygotes (G1 stage) derived from activated MII oocytes followed by $3 \mathrm{~h}$ of in vitro culture. At this time point, more than $99.0 \%$ of the zygotes were observed at the G1 phase. When the activated oocytes were cultured in vitro for $4 \mathrm{~h}, 49.15 \%$ of the resulting zygotes proceeded to the $S$ phase, as manifested by the appearance of nucleoli (Figure 1B). As shown in Table 1, the percentage of activated oocytes that developed to zygotes (S stage) in the Vitrification group was significantly lower $(p<0.05)$ compared to the Control $(27.09 \%$ vs. $49.15 \%$, respectively), indicating that the progression of the G1 into the $S$ phase in embryos derived from vitrified oocytes was retarded. When $10^{-9} \mathrm{~mol} / \mathrm{L}$ MT was added to the culture media used in the entire experiment, the percentage of embryos in the Vitrification group was significantly increased, from $27.09 \%$ to $40.42 \%(p<0.05)$, suggesting that the G1/S transition progression in zygotes was accelerated.

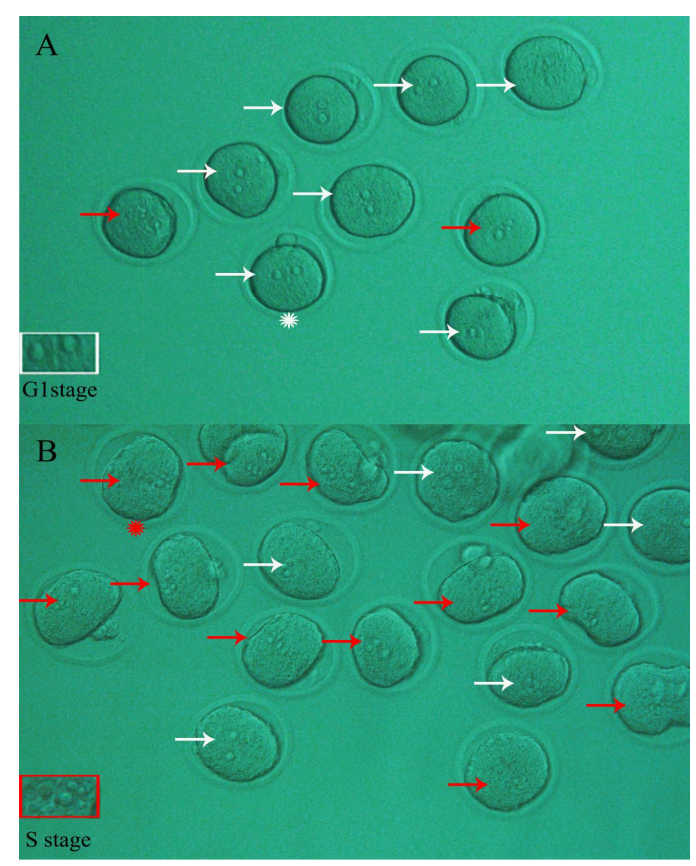

Figure 1. Typical phase showing nucleolus status of parthenogenetic zygotes. After parthenogenetic activation of mouse MII oocytes followed by in vitro culture for 3 to $4 \mathrm{~h}$, the resulting zygotes ((A) $3 \mathrm{~h}$; (B) $4 \mathrm{~h}$ ) were observed under a stereomicroscope for determination of their nucleolus status. The embryos with two separate pronuclei and no apparent nucleoli inside (white arrows) remained at the G1 stage, while those with apparent nucleoli (red arrows) had proceeded through the G1 into the $S$ phase. In Figure 1A, the criterion of pronuclei of parthenogenetic zygote in G1 stage is shown in the white rectangle (zoomed-in frame of corresponding zygote with white asterisk). Similarly, in Figure $1 \mathrm{~B}$, the criterion of pronuclei of parthenogenetic zygote in the $\mathrm{S}$ stage is shown in the red rectangle (zoomed-in frame of corresponding zygote with red asterisk). Original magnification $200 \times$. 
Table 1. Effect of melatonin on the G1/S transition in parthenogenetic zygotes.

\begin{tabular}{ccccccc}
\hline Groups & $\begin{array}{c}\text { No. of } \\
\text { Oocytes } \\
\text { Vitrified }\end{array}$ & $\begin{array}{c}\text { No. of } \\
\text { Oocytes } \\
\text { Recovered }\end{array}$ & $\begin{array}{c}\text { No. of Oocytes } \\
\text { with Normal } \\
\text { Morphology (\%) }\end{array}$ & $\begin{array}{c}\text { No. of } \\
\text { Oocytes } \\
\text { Activated }\end{array}$ & $\begin{array}{c}\text { Zygotes in G1 } \\
\text { Phase (\%) }\end{array}$ & $\begin{array}{c}\text { Zygotes in S Phase } \\
\text { (\%) }\end{array}$ \\
\hline $\begin{array}{c}\text { Control } \\
\text { Vitrification }\end{array}$ & - & 126 & $126(100 \pm 0)^{\mathrm{a}}$ & 118 & $60(50.85 \pm 18.78)^{\mathrm{a}}$ & $58(49.15 \pm 18.78)^{\mathrm{a}}$ \\
Vitrification + MT & 173 & 171 & $158(87.68 \pm 8.22)^{\mathrm{b}}$ & 155 & $113(72.91 \pm 10.89)^{\mathrm{b}}$ & $42(27.09 \pm 10.89)^{\mathrm{b}}$ \\
\hline
\end{tabular}

Morphologically normal oocytes were evaluated by visual inspection of the membrane integrity, the zona pellucida (ZP), and any altered appearance of the cytoplasm (e.g., becoming white, colorless, or dispersed). The number of zygotes with nucleolus (S phase) or without nucleolus (G1 phase) was counted at $4 \mathrm{~h}$ after oocyte parthenogenetic activation (PA). Mouse MII oocytes from "Vitrification group" were first subjected to vitrification/warming and $1 \mathrm{~h}$ of in vitro culture, then to PA followed by in vitro culture of parthenogenetic embryos. During the whole experimental procedure, the other oocytes were treated either with $10^{-9} \mathrm{~mol} / \mathrm{L}$ melatonin (MT) or without MT and vitrification/warming were classified as "Vitrification + MT group" and "Control group", respectively. The experiment was replicated five times. The rate of oocytes with normal morphology $(\%)=($ No. of oocytes with normal morphology/No. of oocytes recovered $) \times 100$. The rate of zygotes in S stage $(\%)=($ No. of zygotes in $S$ stage/No. of oocytes activated) $\times 100$. The values are shown as mean \pm standard deviation (SD). Values with different superscripts ( $\mathrm{a}$ and $\mathrm{b})$ in the same column differ significantly $(p<0.05)$.

\subsection{Melatonin Decreased ROS Levels in Parthenogenetic Zygotes from Vitrified Oocytes}

As shown in Figure 2A, there was no significant difference in ROS levels of mouse MII oocytes when they were cultured in vitro for 0 and $1 \mathrm{~h}$ among the Control, Vitrification and Vitrification + MT groups $(p>0.05)$. When activated oocytes were cultured for $3 \mathrm{~h}$, the resulting zygotes (G1 stage) showed higher ROS levels in the Vitrification group than those of the Control group $(p<0.05)$. However, when MT was added to the medium, the ROS level decreased significantly and was similar to that of Control group $(p>0.05)$.

A

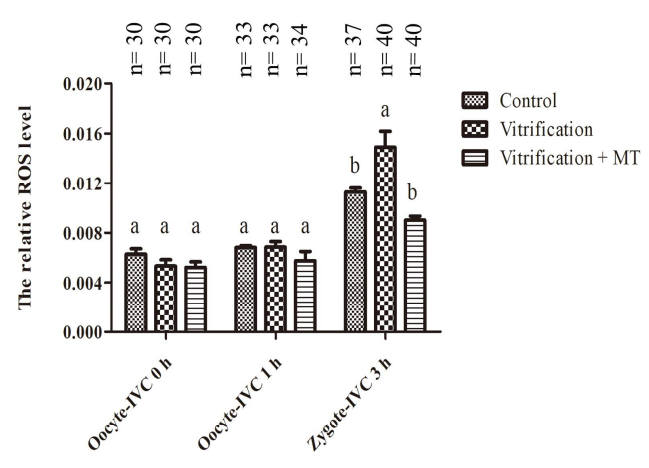

B

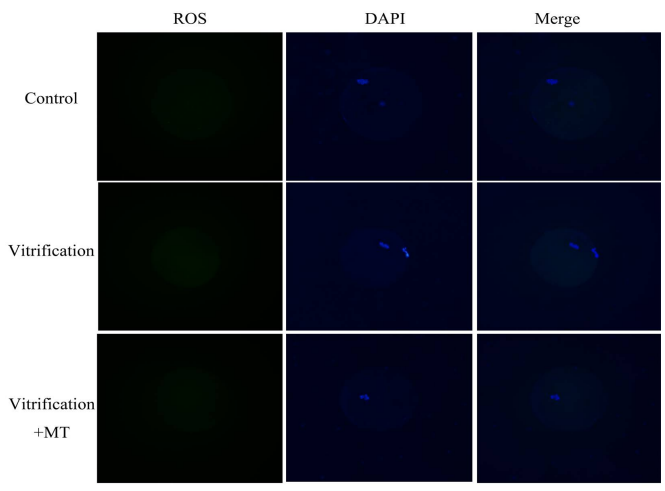

Oocyte-IVC 0 h

Figure 2. Cont. 
$\mathrm{C}$

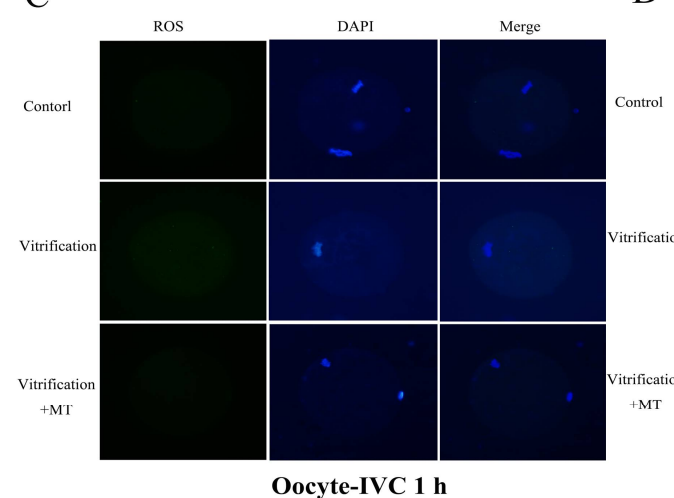

$\mathrm{D}$

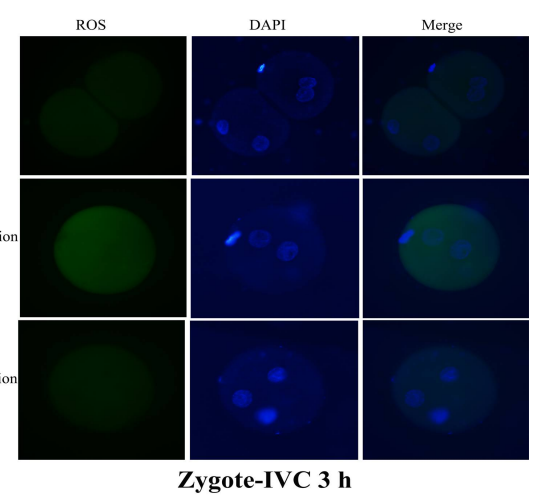

Figure 2. Reactive oxygen species (ROS) levels in mouse MII oocytes and their parthenogenetic zygotes. The dynamic change of ROS levels in mouse oocytes and their parthenogenetic zygotes (A) ROS staining in oocytes $(\mathbf{B}, \mathbf{C})$ and their parthenogenetic zygotes (D) Fluorescence intensities were correlated with intracellular levels of ROS. Different superscripts ( $a$ and $b$ ) represent treatment differences within panels $(p<0.05$ ). After warming, mouse MII oocytes were in vitro cultured for $0 \mathrm{~h}$ (Oocyte-IVC $0 \mathrm{~h}$ ) or $1 \mathrm{~h}$ (Oocyte-IVC $1 \mathrm{~h}$ ) in M2 medium. The oocytes cultured for $1 \mathrm{~h}$ were selected for parthenogenetic activation (PA). During the entire experiment, all the media were supplemented with $10^{-9} \mathrm{~mol} / \mathrm{L}$ (Vitrification + MT group) or $0 \mathrm{~mol} / \mathrm{L}$ melatonin (Vitrification group). Fresh oocytes without melatonin (MT) treatment were used as controls (Control group). After PA and in vitro culture for $3 \mathrm{~h}$, the resulting zygotes (zygote-IVC $3 \mathrm{~h}$ ) were used for ROS detection together with mouse oocytes before PA. The values (the relative ROS levels)) are shown as mean \pm SEM. The experiment was replicated at least three times. Original magnification $200 \times$.

\subsection{Melatonin Decreased GSH Levels in Parthenogenetic Zygotes from Vitrified Oocytes}

As shown in Figure 3A, GSH levels in mouse MII oocytes that were cultured in vitro for either 0 or $1 \mathrm{~h}$ were similar among the Control, Vitrification and Vitrification + MT groups. However, after oocyte activation and $3 \mathrm{~h}$ of in vitro culture, the GSH levels in parthenogenetic zygotes were significantly higher $(p<0.05)$ in the Vitrification group than in the Control group. Supplementation of culture media with MT decreased GSH levels. Following MT supplementation in the culture media, GSH levels were decreased in the Vitrification + MT group and were comparable to the Control group.

A

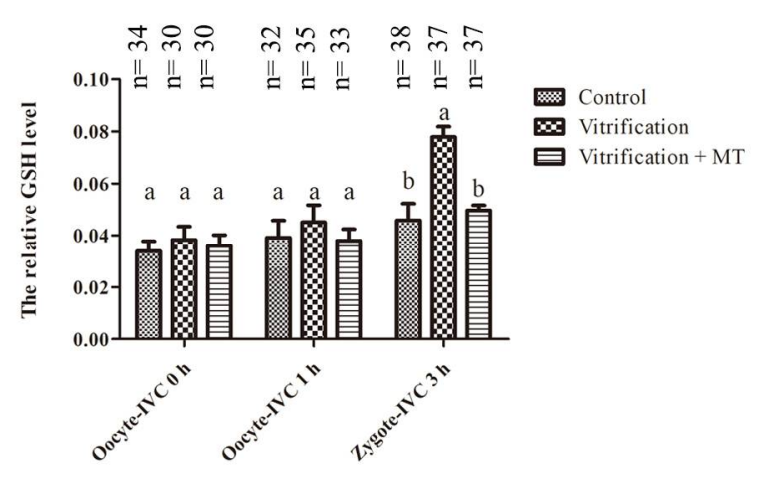

B

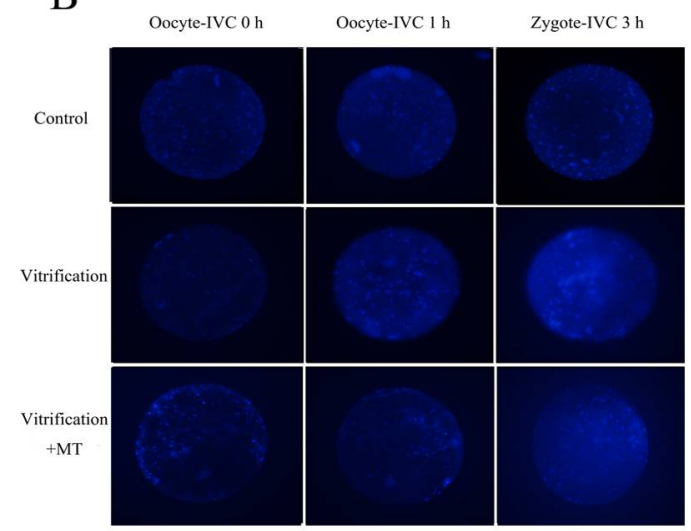

Figure 3. Glutathione (GSH) levels in mouse MII oocytes and their parthenogenetic zygotes. (A) The dynamic change of GSH levels in mouse oocytes and their parthenogenetic zygotes. (B) GSH staining of oocytes and their parthenogenetic zygotes in three groups. Fluorescence intensities were correlated with intracellular levels of GSH. The values (the relative GSH levels) are shown as mean $\pm \mathrm{SEM}$. The experiment was replicated at least three times. Different superscripts ( $a$ and $b$ ) represent treatment differences within panels $(p<0.05)$. Original magnification $200 \times$. 
2.4. Melatonin Altered mRNA Expression of G1 Checkpoint Related Genes in Parthenogenetic Zygotes from Vitrified Oocytes

Parthenogenetic mouse zygotes at the G1 phase were used for the detection of the expression of cell cycle-related genes (P53, P21 and E2F1). As shown in Figure 4A, the mRNA expression of gene $P 53$ in the Vitrification group was significantly higher than that of the Control group $(p<0.05)$. When $10^{-9} \mathrm{~mol} / \mathrm{L}$ MT was added to the media, the P53 expression in the Vitrification + MT group decreased significantly to the level of the Control group. The P21 expression in the Vitrification group was also significantly higher $(p<0.05)$ than in the Control group, and it was markedly decreased after the addition of MT to the culture media (Figure 4B). However, E2F1 expression in the Vitrification group was significantly decreased $(p<0.05)$ when compared with the Control group, and after MT supplementation, it was markedly increased and was similar to that of the Control (Figure 4C). Alterations in the mRNA expression of cell cycle-related genes (P53, P21 and E2F1) due to oocyte vitrification strongly suggested that cell cycle could be arrested at the G1 phase.
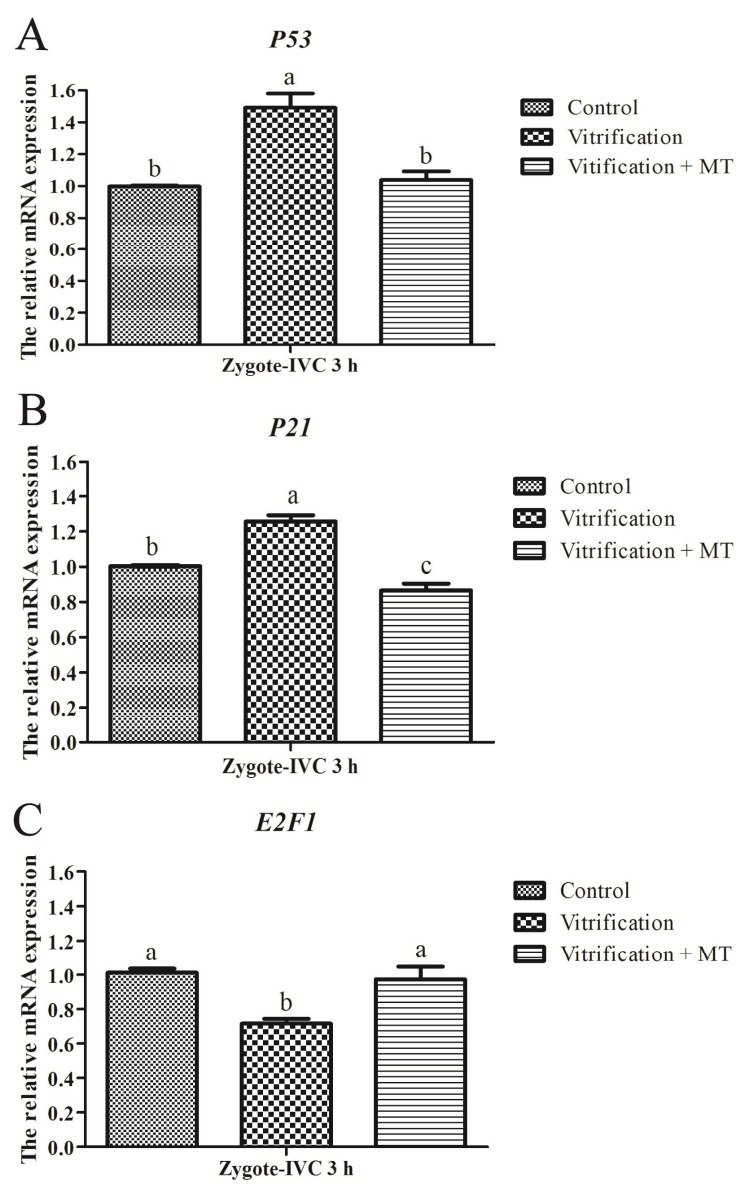

Figure 4. Effect of melatonin on mRNA expression of cell cycle-related genes in parthenogenetic zygotes (G1 stage). (A-C) The relative mRNA expression of cell cycle-related genes (P53, P21 and E2F1) in zygotes at G1 stage. The relative expression levels of mRNA were determined by the $2^{-\triangle \triangle C t}$ method and normalized against that of the reference gene GAPDH (glyceraldehyde 3-phosphate dehydrogenase). All data are mean \pm SEM from three replicates. Different superscripts $(a, b$ and $c)$ represent treatment differences within panels $(p<0.05)$.

\subsection{Melatonin Improved Parthenogenetic Development of Vitrified-Warmed Mouse Oocytes}

After mouse MII oocytes were parthenogenetically activated, the resulting embryos were cultured in KSOM-AA medium. As shown in Table 2, the percentages of activated mouse oocytes that developed into embryos at the 2-cell, 4-cell, morula, blastocyst and hatched blastocyst stages in the Vitrification 
group were significantly lower $(p<0.05)$ than those of the Control group. After supplementation with MT, the percentages were markedly increased and almost recovered to the levels seen in the Control group (except for hatched blastocysts).

Table 2. Melatonin supplementation on parthenogenetic development of cryopreserved mouse MII oocytes.

\begin{tabular}{|c|c|c|c|c|c|c|}
\hline \multirow[b]{2}{*}{ Groups } & \multirow{2}{*}{$\begin{array}{c}\text { No. of } \\
\text { Oocytes } \\
\text { Activated }\end{array}$} & \multicolumn{5}{|c|}{ No. of Activated Oocytes Developed to } \\
\hline & & 2-Cell Embryos (\%) & 4-Cell Embryos (\%) & Morula (\%) & Blastocysts (\%) & $\begin{array}{c}\text { Hatched } \\
\text { Blastocysts (\%) }\end{array}$ \\
\hline Control & 150 & $141(94.00 \pm 2.55)^{\mathrm{a}}$ & $140(93.33 \pm 0.87)^{\mathrm{a}}$ & $129(86.00 \pm 1.94)^{a}$ & $100(66.67 \pm 1.32)^{\mathrm{a}}$ & $50(33.33 \pm 15.35)^{\mathrm{a}}$ \\
\hline Vitrfication & 122 & $90(73.77 \pm 11.96)^{b}$ & $97(79.51 \pm 11.96)^{b}$ & $80(65.57 \pm 12.32)^{b}$ & $41(33.61 \pm 6.54)^{b}$ & $8(6.56 \pm 4.78)^{c}$ \\
\hline Vitrification + MT & 175 & $160(91.43 \pm 9.62)^{a}$ & $165(94.29 \pm 10.06)^{a}$ & $147(84.00 \pm 7.72)^{a}$ & $100(57.14 \pm 16.17)^{\mathrm{a}}$ & $39(22.29 \pm 3.82)^{b}$ \\
\hline
\end{tabular}

\section{Discussion}

Over the past few decades, the success of oocyte vitrification has progressed rapidly; vitrified-warmed oocytes could support development to term of fertilized [48-52] and cloned [53,54] embryos. However, the frequencies of live offspring derived from vitrified-warmed oocytes are unsatisfactory, which may result from such oocyte damage as mitochondrial dysfunction [28,55], DNA damage [56], metabolic disorders [57], and alteration of gene expression [13] due to vitrification, substantially hindering their subsequent developmental potential. Here, this was also confirmed by the fact that the parthenogenetic development of mouse oocytes into blastocysts significantly decreased from $66.67 \%$ to $33.61 \%$ after vitrification. In the present study we tried to elucidate the underlying mechanism by which melatonin promotes the development of vitrified-warmed mouse oocytes in vitro potentially by regulating cell cycle progression, expression of cell cycle-related genes and redox homeostasis.

Generally, in the G1 stage, cells are in an active metabolic state, preparing for synthesis of proteins, RNA and pre-replication complexes needed for DNA replication [58]. At this stage, the G1 checkpoint scrutinizes whether the DNA is complete to ensure normal DNA replication [59]. In the event of an undesirable state for DNA replication, cell cycle progression will be delayed or arrested $[60,61]$. Evidently, in the present study, oocyte vitrification delayed or arrested the G1/S transition in parthenogenetic zygotes. However, when MT $\left(10^{-9} \mathrm{~mol} / \mathrm{L}\right)$ was added to vitrification/warming solutions, and the medium used for oocyte activation/embryonic development, the G1/S transition in zygotes was significantly increased, showing that there was less delay in cell cycle progression. In breast cancer, MT promotes cancer cell apoptosis by blocking the G1/S transition [62]. It seems that the contradictory effects of MT on the regulation of cell cycle progression may be related to the different cell types (embryo vs. breast cancer cells) and/or cellular physiological state (normal vs. pathological). Nevertheless, more studies are required to further elucidate the underlying mechanisms to understand this particular discrepancy.

In the present study, the transcript levels of P53 in parthenogenetic zygotes derived from vitrified-warmed oocytes were significantly up-regulated at the G1 phase compared to the Control group. Increased expression of transcription factor P53 due to oocyte cryopreservation would promote the mRNA expression of P21 via the P53-P21 pathway [36]. When transcription of P21, a cyclin-dependent kinase inhibitor, is increased, it might down-regulate the activity [63] or transcription levels [64] of the E2F transcription factor family including E2F1. The low activity and protein levels of E2F1 thus induce G1 arrest [40,65], which was manifested here by the decreased percentage of parthenogenetic zygotes with nucleoli (S phase) from $49.15 \%$ to $27.09 \%$. When $10^{-9} \mathrm{~mol} / \mathrm{L}$ MT was administered, the transcription level of $P 53$ was significantly decreased in the vitrification group and restored to the level of the Control group, thus promoting the G1/S 
transition in parthenogenetic zygotes through P53-P21-E2F1 pathway and improving their subsequent in vitro development.

The cellular redox balance is required for normal cellular metabolism. However, when oocytes underwent cryopreservation and/or in vitro culture, high levels of ROS production [66] cause an imbalance in the intracellular redox systems, potentially leading to cell apoptosis or dysfunction $[67,68]$. Therefore, it would be beneficial for subsequent development of oocytes to reduce the production of excessive ROS. In the present study, interestingly, at the beginning ( 0 or $1 \mathrm{~h}$ ) of in vitro culture, the levels of both ROS and GSH in vitrified-warmed oocytes were not significantly different in all three groups. At this point, we assumed that intracellular organelles might be in a recovery state following cryopreservation and consequently may have lower metabolic levels. After oocyte activation and in vitro culture for $3 \mathrm{~h}$, the resulting zygotes in the G1 stage exhibited higher levels of ROS in the Vitrification group than in the Control. However, when MT was added to the vitrification group there was no increase in ROS levels, consistent with the improved in vitro development of parthenogenetic embryos. Similarly, GSH levels in parthenogenetic zygotes at G1 stage were also increased after oocyte vitrification, which occurred potentially in response to ROS generation [69]. Another possible reason for the increased GSH levels may result from the higher expression of glutathione reductase and glutathione synthetase due to oocyte vitrification and in vitro culture of embryos. The GSH levels also decreased back to normal levels when MT was administered. The exact mechanism by which MT decreased GSH levels remains to be further investigated.

Recently it has been reported that mitochondrial quiescence is an effective pathway to ameliorate mitochondrial ROS-induced (mROS) oxidative damage in oocytes during in vitro maturation (IVM). Recently, He and colleagues evaluated the mitochondrial activity and expression of mitochondrial DNA (mtDNA) in porcine oocytes following MT treatment. Enhanced IVM rate, lipid droplet (LD) accumulation as well as triglyceride content in porcine oocytes were observed following MT supplementation in IVM medium. Reduced mitochondrial markers, such as mitochondrial membrane potential, mitochondrial respiratory chain complex IV activity and mROS levels, showed implication of MT in inducing a decrease in the mitochondrial activity [70]. Nevertheless, despite these enticing findings, much remains to be elucidated with respect to the potential implication of MT in the mitochondrial function and subsequent impact on outcomes of IVM of oocytes and embryo development.

The developmental potential of oocytes is not only related to their accumulation of maternal stores [71], but also to redox homeostasis in oocytes and preimplantation embryos. In response to external stimuli and/or increased ROS levels appearing during in vitro culture, embryos may show retarded development [72]. Such a negative impact, however, could be alleviated by addition of MT to the culture medium $[13,73]$. In a previous report, we found that vitrification of mouse oocytes increased intracellular ROS levels, and disorganized the mRNA expression of maternal-to-zygotic transition related genes in parthenogenetic 2-cell embryos [13]. In the present study, we further examined ROS and GSH levels and the expression of cell cycle-related genes (P53, P21 and E2F1) in parthenogenetic zygotes at the G1 stage, and found that the increased ROS levels caused by oocyte vitrification would induce the mRNA expression of $P 53$ [74], which thus promoted $P 21$ transcription [38]; this suggests that excessive ROS could delay the division of parthenogenetic zygotes at the G1/S transition phase via the P53-P21 pathway and inhibit their further development. With the addition of MT to the Vitrification group, there were much lower ROS levels, potentially promoting the in vitro development of parthenogenetic zygotes by accelerating the G1/S phase transition via the P53-P21 pathway.

\section{Materials and Methods}

Unless otherwise stated, all chemicals were purchased from Sigma-Aldrich (St. Louis, MO, USA). All animals were maintained and handled in accordance with the requirements of the animal ethical and welfare committee (AEWC) of Sichuan Agricultural University (approval code: AEWC2016, 6 January 2016). 


\subsection{Oocyte Collection}

Outbred female ICR mice (Dashuo Company, Chengdu, China) aged 6 weeks were kept in autoclaved cages in a room under standard conditions of a 14:10 light/dark cycle (light on at 06:00). After two weeks of acclimation, female mice were induced to superovulate by an initial intraperitoneal injection of 5 IU equine chorionic gonadotropin (PMSG, NingBo second hormone factory, Ningbo, China), and $48 \mathrm{~h}$ later 5 IU human chorionic gonadotropin (hCG, NingBo second hormone factory, Ningbo, China) was injected to trigger ovulation. Cumulus-oocyte complexes were collected from oviducts 12-14 h after hCG treatment and recovered in M2 medium [75] supplemented with $3 \mathrm{mg} / \mathrm{mL}$ bovine serum albumin. Cumulus cells were dispersed with $300 \mathrm{IU} / \mathrm{mL}$ hyaluronidase and then washed a minimum of 3 times in M2 for the subsequent experiments. During the entire experiment, we collected more than 2000 mouse oocytes, and 1870 were selected for use.

\subsection{Oocyte Vitrification and Warming}

Open-pulled straws (OPS) were made according to the method described previously [76,77]. Briefly, the straws ( $250 \mathrm{~mL}$; IMV, L'Aigle, France) were heat-softened and pulled manually to produce a straw approximately $3 \mathrm{~cm}$ in length, $0.10 \mathrm{~mm}$ inner diameter, and $0.15 \mathrm{~mm}$ outer diameter.

Oocytes were vitrified using an OPS method. They were first equilibrated in $10 \%$ ethylene glycol (EG) $+10 \%$ dimethyl sulfoxide (DMSO) for $30 \mathrm{~s}$, then loaded into the narrow end of an OPS with EDFS30 solution consisting of Dulbecco's Phosphate Buffered Saline (DPBS) medium containing $300 \mathrm{~g} / \mathrm{L}$ Ficoll, $0.5 \mathrm{~mol} / \mathrm{L}$ sucrose, and 20\% fetal bovine serum (FBS), 15\% $(v / v)$ EG and $15 \%(v / v)$ DMSO, with exposure for $25 \mathrm{~s}$. Finally, the straws containing oocytes (8 oocytes per OPS) were quickly plunged into liquid nitrogen.

For warming, oocytes were rinsed in $0.5 \mathrm{~mol} / \mathrm{L}$ sucrose for $5 \mathrm{~min}$, then washed 3 times in M2 medium and incubated in an incubator (Thermo Electron Corporation, Marietta, OH, USA) at $37.5^{\circ} \mathrm{C}$ with $5 \% \mathrm{CO} 2$ in air for $1 \mathrm{~h}$ in $\mathrm{M} 2$ medium. All manipulations were performed at $37^{\circ} \mathrm{C}$ on a warming stage fixed onto the stereomicroscope stage, and the ambient atmosphere was air-conditioned at a temperature of $25 \pm 0.5^{\circ} \mathrm{C}$.

Before vitrification, oocytes were pooled and randomly distributed to each group (Control, Vitrification and Vitrification + MT). In the Vitrification + MT group, all the media (10\% EG + 10\% DMSO, EDFS30, $0.5 \mathrm{~mol} / \mathrm{L}$ sucrose and M2) were supplemented with $10^{-9} \mathrm{~mol} / \mathrm{L}$ of MT, while the Control and Vitrification groups did not contain MT.

\subsection{Oocyte Parthenogenetic Activation and Embryo Culture}

All oocytes were allowed to recover in a $\mathrm{CO}_{2}$ incubator for $1 \mathrm{~h}$ before parthenogenetic activation. The activation medium was $\mathrm{Ca}^{2+}$-free human tubal fluid (HTF) [78] supplemented with $10 \mathrm{mmol} / \mathrm{L}$ $\mathrm{SrCl}_{2}$ and $2 \mu \mathrm{g} / \mathrm{mL}$ cytochalasin D [79]. After being washed 3 times in activation medium, oocytes were incubated first in activation medium for $2.5 \mathrm{~h}$ and then in regular HTF supplemented with $2 \mu \mathrm{g} / \mathrm{mL}$ cytochalasin $\mathrm{D}$ for $3.5 \mathrm{~h}$ at $37.5^{\circ} \mathrm{C}$ in a $\mathrm{CO}_{2}$ incubator. Finally, oocytes were removed from the above media and cultured in KSOM-AA with D-Glucose and Phenol Red medium [80] (CAT\# MR-121-D, Millipore, Temecula, CA, USA) for $120 \mathrm{~h}$. Embryo development was assessed at 24, 48, 72, 96 and $120 \mathrm{~h}$ after the start of culture. All the media in this experimental procedure were supplemented with $10^{-9} \mathrm{~mol} / \mathrm{L}$ of MT only in the vitrification + MT group.

\subsection{Detection of Cell Cycle Progression}

Cell cycle procession in mouse embryos was assessed according to the method described previously [81]. In brief, according to the developmental morphology of the one-cell embryo derived from fertilized oocyte in vivo: at G1 phase, $12-21 \mathrm{~h}$ post-hCG injection, a space is evident between two pronuclei; at $S$ phase, $21-27 \mathrm{~h}$, two pronuclei are located very close to each other with the appearance of nucleoli; at G2 phase, 27-30 h, the profile of two pronuclei disappears in one-cell embryo and 
large particle appears in cytoplasm; at M phase, $30-33 \mathrm{~h}$, the cellular body elongates and cytoplasmic division appears in the one-cell embryo. Therefore, bearing in mind the foregoing descriptions, we observed the morphology of parthenogenetic zygotes under an inverted phase contrast microscope (IX70, Olympus, Tokyo, Japan). When there was a space between the two pronuclei and no nucleoli, zygotes were classified to be at the G1 phase, and when there were two pronuclei located very close to each other with the appearance of nucleoli, zygotes were classified to have proceeded into $S$ phase.

\subsection{Measurement of Intracellular ROS and GSH}

Mouse MII oocytes and their parthenogenetic zygotes at G1 phase were collected to determine the intracellular ROS and GSH levels according to a previous report [82]. To measure intracellular ROS levels, more than 10 oocytes or embryos from each treatment group were incubated (in the dark) in M2 supplemented with $1 \mathrm{mmol} / \mathrm{L}$ 2, 7-dichlorodihydrofluorescein diacetate (H2DCFDA, Invitrogen, Carlsbad, CA, USA) for $20 \mathrm{~min}$ at $37^{\circ} \mathrm{C}$, washed 3 times in $\mathrm{M} 2$ medium containing $3 \mathrm{mg} / \mathrm{ml}$ bovine serum albumin, and then placed into $6 \mu \mathrm{L}$ droplets of fluorescent mounting medium with DAPI (Vector Laboratories Inc., Burlingame, CA, USA) on a slide, then covered with a cover slip. Fluorescence was measured under an epifluorescence microscope with a filter at 460-nm excitation, and fluorescence images were recorded as TIFF files using a camera (BX53, Olympus, Tokyo, Japan). The recorded fluorescence intensities were quantified using Image J software (version 1.48; National Institutes of Health, Bethesda, MD, USA) after deducting the background value. The level of GSH in each oocyte was measured with $10 \mu \mathrm{mol} / \mathrm{L}$ 4-chloromethyl-6.8-difluoro-7-hydroxycoumarin (Cell-Tracker Blue, Invitrogen, Carlsbad, CA, USA) with a filter at 370-nm excitation. The experimental procedure was the same as the ROS measurement described above. The experiment was replicated 3 times.

\subsection{Quantitative Polymerase Chain Reaction (Q-PCR)}

Total complementary DNA (cDNA) was isolated from 20-25 parthenogenetic zygotes at the G1 stage for each group by using TransScript-Uni Cell to cDNA Synthesis SuperMix for Q-PCR (TransGen Biotech, Beijing, China). A total of 195 zygotes (Control: $n=65$; Vitrification: $n=65$; Vitrification + MT: $n=65$ ) were collected for the Q-PCR test. Then, the cDNA was quantified by Q-PCR using TransStart Tip Green qPCR SuperMix (TransGen Biotech, Beijing, China) on a CFX Connect Real-Time Detection System (Bio-Rad, Hercules, CA, USA) under standard conditions. The cycle threshold (Ct) value used to calculate the relative expression was the average of 3 replicates and was normalized against that of the reference gene $(G A P D H)$. The primer information is summarized in Table 3. The mRNA expression levels were calculated using the $2^{-\triangle \triangle \mathrm{Ct}}$ method [83].

Table 3. PCR primers used for SYBR green Q-PCR analysis.

\begin{tabular}{ccccc}
\hline Gene & Assay ID & Primer seq $\left(5^{\prime}-\mathbf{3}^{\prime}\right)$ & Product Length & Tm $\left({ }^{\circ} \mathbf{C}\right)$ \\
\hline P53 & NM_001127233.1 & $\begin{array}{c}\text { F: AGGATTGTGGCCTTCTTTGA } \\
\text { R: CAGATGCCGGTCAGGTACT }\end{array}$ & 126 & 62 \\
F21 & NM_001111099.2 & $\begin{array}{c}\text { F: TGGAGATGAACTGGACAGCA } \\
\text { R: TGAAGTTGCCATCAGCAAAC }\end{array}$ & 84 & 62 \\
F2F1 & NM_001291105.1 & $\begin{array}{c}\text { F: CGAGTCCTATGCCTTCAACA } \\
\text { R: GAGTCCAGCCAGGAGATGAC }\end{array}$ & 159 & 62 \\
GAPDH & NM_001289726.1 & $\begin{array}{c}\text { F: AGAACATCATCCCTGCATCC } \\
\text { R: AGATCCACGACGGACACATT }\end{array}$ & 124 & 62 \\
\hline
\end{tabular}

\subsection{Experimental Design}

Based on our previous results [13], we selected $10^{-9} \mathrm{~mol} / \mathrm{L}$ MT for the present study. The experimental design is shown in Figure 5. In experiment 1, the effect of MT was examined on cell cycle procession transition (G1/S) in parthenogenetic mouse zygotes. Mouse MII oocytes were first subjected to vitrification/warming and $1 \mathrm{~h}$ of in vitro culture, then to parthenogenetic activation (PA) followed by in vitro culture of the parthenogenetic embryos. The percentage of activated oocytes 
developing to parthenogenetic zygotes at the $S$ stage was assessed to determine the effect of MT on the G1/S transition.

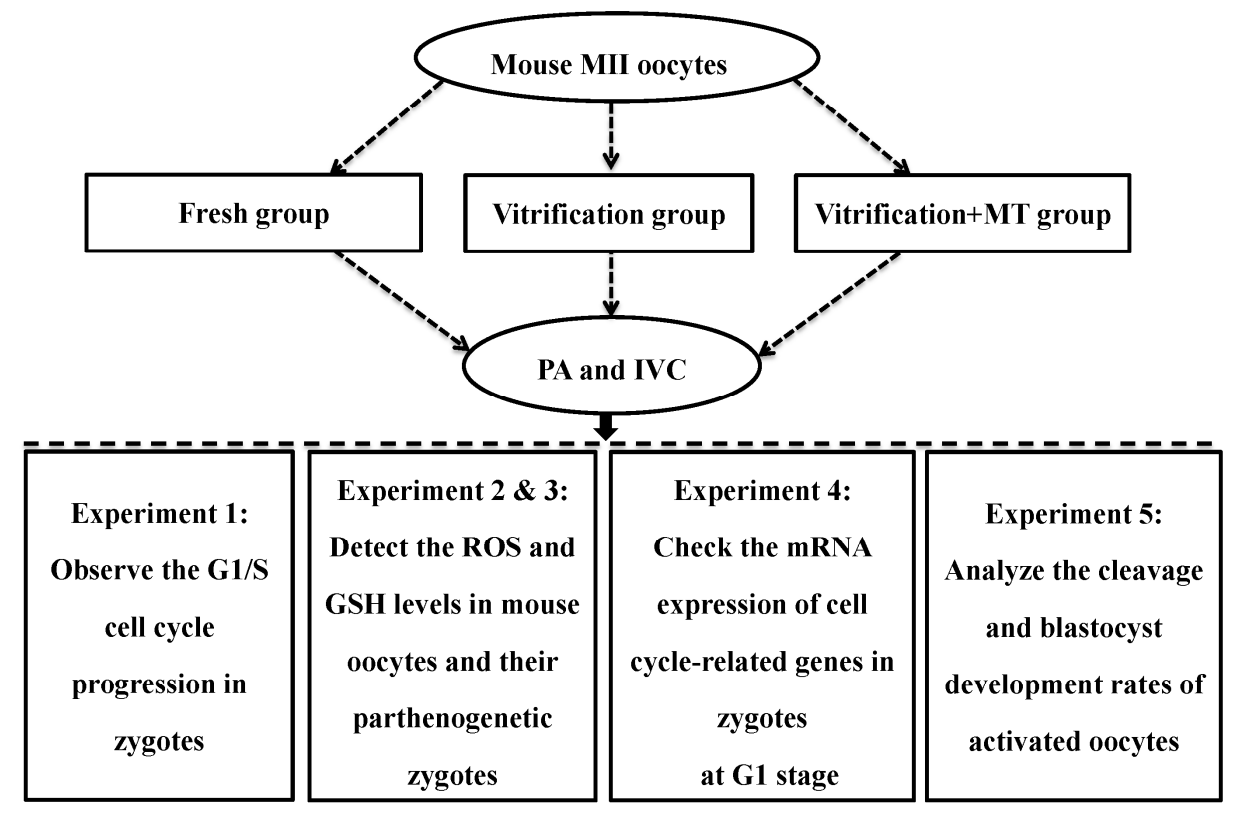

Figure 5. Flowchart of experimental design. Control group: untreated mouse MII oocytes; Vitrification group: oocytes were vitrified by the open-pulled straw method without melatonin (MT) addition; Vitrification + MT group: oocytes were treated with MT at a final concentration of $10^{-9} \mathrm{~mol} / \mathrm{L}$ in all the media used in the entire experiment; PA: parthenogenetic activation; IVC: in vitro culture; MT: melatonin.

In experiments 2 and 3, the effect of MT on ROS and GSH levels in vitrified-warmed MII oocytes and their parthenogenetic zygotes was examined. Oocytes cultured for 0 or $1 \mathrm{~h}$ in $\mathrm{M} 2$ medium and their parthenogenetic zygotes (G1 stage) were collected to detect ROS and GSH levels. We set the culture time ( 0,1 and $3 \mathrm{~h}$ ) based on the following considerations: (1) ROS and GSH levels in the oocytes were tested immediately (no culture, $0 \mathrm{~h}$ ) after they were warmed, acting as a basal level. (2) When cultured in vitro for $1 \mathrm{~h}$, the vitrified-warmed mouse oocytes almost recovered to a normal physiological state, which is suitable for PA. At this timepoint, we checked ROS and GSH concentrations to represent the normal physiological levels. (3) After PA and in vitro culture for $3 \mathrm{~h}$, almost all the parthenogenetic zygotes were at the G1 stage. However, when the in vitro culture time was extended to $4 \mathrm{~h}, 49.15 \%$ of zygotes (Control group) proceeded to the $S$ phase. Therefore, we selected parthenogenetic zygotes at the G1 stage ( $3 \mathrm{~h}$ ) for assessing ROS and GSH levels.

In experiment 4, the effect of MT was investigated on cell cycle-related genes of parthenogenetic zygotes (G1 stage). The expression of these genes (P53, P21 and E2F1) was determined by Q-PCR as described above.

In experiment 5, the effect of MT was tested on the in vitro development of parthenogenetic embryos derived from cryopreserved oocytes. The rates of cleavage (2-cells), and development to 4-cell embryos, morula, blastocyst and hatched blastocyst were assessed.

\subsection{Statistical Analysis}

All experiments were replicated at least 3 times. The percentages of activated oocytes that developed to zygotes in the G1/S phase and to subsequent embryos at the 2-cell, 4-cell, morula, blastocyst and hatched blastocyst stages were analyzed by the chi-squared test. Statistical analysis of ROS levels, GSH levels and gene expression was conducted by one-way ANOVA followed by the LSD test using SPSS (Version 20) statistical software (IBM, Chicago, IL, USA). Data were expressed 
as the mean \pm standard error or mean \pm standard deviation (SD), and $p<0.05$ was considered statistically significant.

\section{Conclusions}

To sum up, mouse MII oocyte vitrification resulted in disturbances of the mRNA expression of cell cycle-related genes (P53, P21 and E2F1), increased ROS and GSH levels in parthenogenetic zygotes, and decreased embryonic development in vitro after oocyte activation. Supplementation of media with $10^{-9} \mathrm{~mol} / \mathrm{L}$ melatonin improved the in vitro development of parthenogenetic zygotes by regulating redox homeostasis (ROS/GSH) and the expression of cell cycle-related genes (P53, P21 and E2F1).

Author Contributions: B.P. was responsible for the experiment, data analysis and paper writing. H.Y. was responsible for the experiment and proofreading the manuscript. Z.W., I.H.Q. and H.Y. took part in laboratory animal husbandry. I.H.Q., G.L., H.H. and Q.M. took part in the discussion, revision, and proofreading of the manuscript. G.Z. was responsible for experimental design, supervised the experiments and revised the manuscript.

Funding: This work was supported in part by the National Natural Science Foundation of China (Grant No. 31572398), the China Agriculture Research System (Grant No. CARS-36), and by the national genetically modified organisms breeding major projects (Grant No.2014ZX0800802B).

Acknowledgments: We would like to thank Professor Barry Bavister for critical reading of the manuscript.

Conflicts of Interest: The authors declare no conflict of interest.

\section{Abbreviations}

$\begin{array}{ll}\text { DMSO } & \begin{array}{l}\text { dimethyl sulfoxide } \\ \text { dulbecco's phosphate buffered saline }\end{array} \\ \text { DPBS } & 4^{\prime} \text {,6-diamidino-2-phenylindole } \\ \text { DAPI } & \text { ethylene glycol } \\ \text { EG } & \text { fetal bovine serum } \\ \text { FBS } & \text { glyceraldehyde 3-phosphate dehydrogenase } \\ \text { GAPDH } & \text { glutathione } \\ \text { GSH } & \text { in vitro culture } \\ \text { IVC } & \text { in vitro maturation } \\ \text { IVM } & \text { lipid droplets } \\ \text { LDs } & \text { mitochondrial DNA } \\ \text { mtDNA } & \text { metaphase II } \\ \text { MII } & \text { melatonin } \\ \text { MT } & \text { open-pulled straws } \\ \text { OPS } & \text { parthenogenetic activation } \\ \text { PA } & \text { quantitative polymerase chain reaction } \\ \text { Q-PCR } & \text { reactive oxygen species } \\ \text { ROS } & \text { zona pellucida } \\ \text { ZP } & \end{array}$

\section{References}

1. Fabbri, R.; Porcu, E.; Marsella, T.; Rocchetta, G.; Venturoli, S.; Flamigni, C. Human oocyte cryopreservation: New perspectives regarding oocyte survival. Hum. Reprod. 2001, 16, 411-416. [CrossRef] [PubMed]

2. Niemann, H. Cryopreservation of ova and embryos from livestock: Current status and research needs. Theriogenology 1991, 35, 109-124. [CrossRef]

3. Kuwayama, M. Highly efficient vitrification for cryopreservation of human oocytes and embryos: The Cryotop method. Theriogenology 2007, 67, 73-80. [CrossRef] [PubMed]

4. Singh, B.; Mal, G.; Singla, S.K. Chapter 18 Vitrification: A Reliable Method for Cryopreservation of Animal Embryos. Methods Mol. Biol. 2017, 1568, 243-249. [CrossRef] [PubMed] 
5. Porcu, E.; Venturoli, S.; Damiano, G.; Ciotti, P.M.; Notarangelo, L.; Paradisi, R.; Moscarini, M.; Ambrosini, G. Healthy twins delivered after oocyte cryopreservation and bilateral ovariectomy for ovarian cancer. Reprod. Biomed. Online 2008, 17, 265-267. [CrossRef]

6. Oktay, K.; Bedoschi, G. Oocyte cryopreservation for fertility preservation in postpubertal female children at risk for premature ovarian failure due to accelerated follicle loss in turner syndrome or cancer treatments. J. Pediatr. Adolesc. Gynecol. 2014, 27, 342-346. [CrossRef] [PubMed]

7. Kotera, T.; Shibata, T.; Kato, H.; Watanabe, H.; Nakago, S. Twin pregnancy in a 51-year-old woman who underwent autologous cryopreservation at the age of 36 years: Case report. Reprod. Med. Biol. 2016, 15, 187-189. [CrossRef]

8. Turner, S.R.; Senaratna, T.; Bunn, E.; Tan, B.; Dixon, K.W.; Touchell, D.H. Cryopreservation of Shoot Tips from Six Endangered Australian Species using a Modified Vitrification Protocol. Ann. Bot. 2001, 87, 371-378. [CrossRef]

9. Taylor-Robinson, A.W.; Walton, S.; Swain, D.L.; Walsh, K.B.; Vajta, G. The potential for modification in cloning and vitrification technology to enhance genetic progress in beef cattle in Northern Australia. Anim. Reprod. Sci. 2014, 148, 91-96. [CrossRef]

10. Matsas, D.; Huntress, V.; Levine, H.; Saperstein, G.; Overstrom, E.W. 108 cryopreservation of germplasm from heritage breeds of domestic livestock: Seasonal effects on superovulation response and embryo production. Reprod. Fertil. Dev. 2003, 16, 176. [CrossRef]

11. Punyawai, K.; Anakkul, N.; Srirattana, K.; Aikawa, Y.; Sangsritavong, S.; Nagai, T.; Imai, K.; Parnpai, R. Comparison of Cryotop and micro volume air cooling methods for cryopreservation of bovine matured oocytes and blastocysts. J. Reprod. Dev. 2015, 61, 431-437. [CrossRef] [PubMed]

12. Somfai, T.; Yoshioka, K.; Tanihara, F.; Kaneko, H.; Noguchi, J.; Kashiwazaki, N.; Nagai, T.; Kikuchi, K. Generation of live piglets from cryopreserved oocytes for the first time using a defined system for in vitro embryo production. PLoS ONE 2014, 9, e97731. [CrossRef] [PubMed]

13. Zhang, Y.; Li, W.; Ma, Y.; Wang, D.; Zhao, X.; Zeng, C.; Zhang, M.; Zeng, X.; Meng, Q.; Zhou, G. Improved development by melatonin treatment after vitrification of mouse metaphase II oocytes. Cryobiology 2016, 73, 335-342. [CrossRef] [PubMed]

14. Ren, L.; Fu, B.; Ma, H.; Liu, D. Effects of mechanical delipation in porcine oocytes on mitochondrial distribution, ROS activity and viability after vitrification. Cryo. Lett. 2015, 36, 30-36.

15. Cao, X.; Li, J.; Xue, H.; Wang, S.; Zhao, W.; Du, Z.; Yang, Y.; Yue, Z. Effect of vitrification on meiotic maturation, mitochondrial distribution and glutathione synthesis in immature silver fox cumulus oocyte complexes. Theriogenology 2017, 91, 104-111. [CrossRef] [PubMed]

16. Monzo, C.; Haouzi, D.; Roman, K.; Assou, S.; Dechaud, H.; Hamamah, S. Slow freezing and vitrification differentially modify the gene expression profile of human metaphase II oocytes. Hum. Reprod. 2012, 27, 2160-2168. [CrossRef] [PubMed]

17. Huang, J.; Ma, Y.; Wei, S.; Pan, B.; Qi, Y.; Hou, Y.; Meng, Q.; Zhou, G.; Han, H. Dynamic changes in the global transcriptome of bovine germinal vesicle oocytes after vitrification followed by in vitro maturation. Reprod. Fertil. Dev. 2018. [CrossRef]

18. Ma, Y.; Pan, B.; Yang, H.; Qazi, I.H.; Wu, Z.; Zeng, C.; Zhang, M.; Meng, Q.; Zhou, G. Expression of CD9 and CD81 in bovine germinal vesicle oocytes after vitrification followed by in vitro maturation. Cryobiology 2018, 81, 206-209. [CrossRef]

19. Forman, H.J.; Maiorino, M.; Ursini, F. Signaling functions of reactive oxygen species. Biochemistry 2010, 49, 835-842. [CrossRef]

20. Paulsen, C.E.; Carroll, K.S. Orchestrating Redox Signaling Networks through Regulatory Cysteine Switches. ACS Chem. Biol. 2010, 5, 47-62. [CrossRef]

21. Cabiscol, E.; Tamarit, J.; Ros, J. Oxidative stress in bacteria and protein damage by reactive oxygen species. Int. Microbiol. 2000, 3, 3-8. [PubMed]

22. Lipinski, B. Hydroxyl radical and its scavengers in health and disease. Oxid. Med. Cell Longev. 2011, 2011, 809696. [CrossRef] [PubMed]

23. Potts, R.J.; Notarianni, L.J.; Jefferies, T.M. Seminal plasma reduces exogenous oxidative damage to human sperm, determined by the measurement of DNA strand breaks and lipid peroxidation. Mutat. Res. 2000, 447, 249-256. [CrossRef] 
24. Munday, R.; Winterbourn, C.C. Reduced glutathione in combination with superoxide dismutase as an important biological antioxidant defence mechanism. Biochem. Pharmacol. 1989, 38, 4349-4352. [CrossRef]

25. Handy, D.E.; Loscalzo, J. Redox regulation of mitochondrial function. Antioxid. Redox. Signal. 2012, 16, 1323-1367. [CrossRef] [PubMed]

26. Fang, C.; Wei, X.; Zhang, Z.; Xianmei, L.I.; Zhang, X.; University, G. Effects of Vitrified Cryopreservation on GSH Content and Mitochondrial ATPase Activity in Oocytes of Zebrafish Danio rerio. Fish. Sci. 2017, 36, 773-777.

27. Somfai, T.; Ozawa, M.; Noguchi, J.; Kaneko, H.; Kuriani Karja, N.W.; Farhudin, M.; Dinnyés, A.; Nagai, T.; Kikuchi, K. Developmental competence of in vitro-fertilized porcine oocytes after in vitro maturation and solid surface vitrification: Effect of cryopreservation on oocyte antioxidative system and cell cycle stage. Cryobiology 2007, 55, 115-126. [CrossRef]

28. Nohales-Corcoles, M.; Sevillano-Almerich, G.; Di Emidio, G.; Tatone, C.; Cobo, A.C.; Dumollard, R.; De Los Santos Molina, M.J. Impact of vitrification on the mitochondrial activity and redox homeostasis of human oocyte. Hum. Reprod. 2016, 31, 1850-1858. [CrossRef]

29. Takahashi, M. Oxidative stress and redox regulation on in vitro development of mammalian embryos. J. Reprod. Dev. 2012, 58, 1-9. [CrossRef]

30. Zhang, C.; Liu, C.; Li, D.; Yao, N.; Yuan, X.; Yu, A.; Lu, C.; Ma, X. Intracellular redox imbalance and extracellular amino acid metabolic abnormality contribute to arsenic-induced developmental retardation in mouse preimplantation embryos. J. Cell Physiol. 2010, 222, 444-455. [CrossRef]

31. Spricigo, J.F.; Morato, R.; Arcarons, N.; Yeste, M.; Dode, M.A.; Lopez-Bejar, M.; Mogas, T. Assessment of the effect of adding L-carnitine and/or resveratrol to maturation medium before vitrification on in vitro-matured calf oocytes. Theriogenology 2017, 89, 47-57. [CrossRef]

32. Castillo-Martin, M.; Yeste, M.; Soler, A.; Morato, R.; Bonet, S. Addition of L-ascorbic acid to culture and vitrification media of IVF porcine blastocysts improves survival and reduces HSPA1A levels of vitrified embryos. Reprod. Fertil. Dev. 2015, 27, 1115-1123. [CrossRef] [PubMed]

33. Boonkusol, D.; Gal, A.B.; Bodo, S.; Gorhony, B.; Kitiyanant, Y.; Dinnyes, A. Gene expression profiles and in vitro development following vitrification of pronuclear and 8-cell stage mouse embryos. Mol. Reprod. Dev. 2006, 73, 700-708. [CrossRef]

34. Majidi Gharenaz, N.; Movahedin, M.; Mazaheri, Z. Effects of Re-Vitrification of Mouse Morula and Early Blastocyst Stages on Apoptotic Gene Expression and Developmental Potential. Cell J. 2018, 19, 614-619. [CrossRef] [PubMed]

35. Zhou, G.; Zeng, Y.; Guo, J.; Meng, Q.; Meng, Q.; Jia, G.; Cheng, K.; Zeng, C.; Zhang, M.; Liu, G.; et al. Vitrification transiently alters Oct-4, Bcl2 and P53 expression in mouse morulae but does not affect embryo development in vitro. Cryobiology 2016, 73, 120-125. [CrossRef]

36. Miyauchi, H.; Minamino, T.; Tateno, K.; Kunieda, T.; Toko, H.; Komuro, I. Akt negatively regulates the in vitro lifespan of human endothelial cells via a p53/p21-dependent pathway. EMBO J. 2004, 23, 212-220. [CrossRef] [PubMed]

37. Mikule, K.; Delaval, B.; Kaldis, P.; Jurcyzk, A.; Hergert, P.; Doxsey, S. Loss of centrosome integrity induces p38-p53-p21-dependent G1-S arrest. Nat. Cell Biol. 2007, 9, 160-170. [CrossRef]

38. Waldman, T.; Kinzler, K.W.; Vogelstein, B. p21 Is Necessary for the p53-mediated G1 Arrest in Human Cancer Cells. Cancer Res. 1995, 55, 5187-5190. [PubMed]

39. Kagawa, S.; Fujiwara, T.; Hizuta, A.; Yasuda, T.; Zhang, W.W.; Roth, J.A.; Tanaka, N. p53 expression overcomes p21WAF1/CIP1-mediated G1 arrest and induces apoptosis in human cancer cells. Oncogene 1997, 15, 1903-1909. [CrossRef]

40. DeGregori, J.; Kowalik, T.; Nevins, J.R. Cellular targets for activation by the E2F1 transcription factor include DNA synthesis- and G1/S-regulatory genes. Mol. Cell. Biol. 1995, 15, 4215-4224. [CrossRef]

41. Madan, E.; Gogna, R.; Kuppusamy, P.; Bhatt, M.; Pati, U.; Mahdi, A.A. TIGAR induces p53-mediated cell-cycle arrest by regulation of RB-E2F1 complex. Br. J. Cancer 2012, 107, 516-526. [CrossRef] [PubMed]

42. Zhang, K.; Dai, L.; Zhang, B.; Xu, X.; Shi, J.; Fu, L.; Chen, X.; Li, J.; Bai, Y. miR-203 is a direct transcriptional target of E2F1 and causes G1 arrest in esophageal cancer cells. J. Cell. Physiol. 2015, 230, 903-910. [CrossRef] [PubMed] 
43. Berlinguer, F.; Leoni, G.G.; Succu, S.; Spezzigu, A.; Madeddu, M.; Satta, V.; Bebbere, D.; Contreras-Solis, I.; Gonzalez-Bulnes, A.; Naitana, S. Exogenous melatonin positively influences follicular dynamics, oocyte developmental competence and blastocyst output in a goat model. J. Pineal Res. 2009, 46, 383-391. [CrossRef] [PubMed]

44. Wang, S.; Liu, B.; Liu, W.; Xiao, Y.; Zhang, H.; Yang, L. The effects of melatonin on bovine uniparental embryos development in vitro and the hormone secretion of COCs. PeerJ 2017, 5, e3485. [CrossRef] [PubMed]

45. Soto-Heras, S.; Roura, M.; Catala, M.G.; Menendez-Blanco, I.; Izquierdo, D.; Fouladi-Nashta, A.A.; Paramio, M.T. Beneficial effects of melatonin on in vitro embryo production from juvenile goat oocytes. Reprod. Fertil. Dev. 2018, 30, 253-261. [CrossRef] [PubMed]

46. Mediavilla, M.D.; Sanchez-Barcelo, E.J.; Tan, D.X.; Manchester, L.; Reiter, R.J. Basic mechanisms involved in the anti-cancer effects of melatonin. Curr. Med. Chem. 2010, 17, 4462-4481. [CrossRef] [PubMed]

47. Mandawala, A.; Harvey, S.; Roy, T.; Fowler, K. Cryopreservation of animal oocytes and embryos: Current progress and future prospects. Theriogenology 2016, 86, 1637-1644. [CrossRef]

48. Vieira, A.D.; Mezzalira, A.; Barbieri, D.P.; Lehmkuhl, R.C.; Rubin, M.I.; Vajta, G. Calves born after open pulled straw vitrification of immature bovine oocytes. Cryobiology 2002, 45, 91-94. [CrossRef]

49. Fujiwara, K.; Kamoshita, M.; Kato, T.; Ito, J.; Kashiwazaki, N. Generation of rats from vitrified oocytes with surrounding cumulus cells via in vitro fertilization with cryopreserved sperm. Anim. Sci. J. 2017, 88, 180-184. [CrossRef]

50. Jimenez-Trigos, E.; Vicente, J.S.; Marco-Jimenez, F. First pregnancy and live birth from vitrified rabbit oocytes after intraoviductal transfer and in vivo fertilization. Theriogenology 2014, 82, 599-604. [CrossRef]

51. Kim, M.K.; Lee, D.R.; Han, J.E.; Kim, Y.S.; Lee, W.S.; Won, H.J.; Kim, J.W.; Yoon, T.K. Live birth with vitrified-warmed oocytes of a chronic myeloid leukemia patient nine years after allogenic bone marrow transplantation. J. Assist. Reprod. Genet. 2011, 28, 1167-1170. [CrossRef] [PubMed]

52. Kono, T.; Kwon, O.Y.; Nakahara, T. Development of vitrified mouse oocytes after in vitro fertilization. Cryobiology 1991, 28, 50-54. [CrossRef]

53. Hou, Y.P.; Dai, Y.P.; Zhu, S.E.; Zhu, H.B.; Wu, T.Y.; Gong, G.C.; Wang, H.P.; Wang, L.L.; Liu, Y.; Li, R.; et al. Bovine oocytes vitrified by the open pulled straw method and used for somatic cell cloning supported development to term. Theriogenology 2005, 64, 1381-1391. [CrossRef] [PubMed]

54. Yang, B.C.; Im, G.S.; Kim, D.H.; Yang, B.S.; Oh, H.J.; Park, H.S.; Seong, H.H.; Kim, S.W.; Ka, H.H.; Lee, C.K. Development of vitrified-thawed bovine oocytes after in vitro fertilization and somatic cell nuclear transfer. Anim. Reprod. Sci. 2008, 103, 25-37. [CrossRef] [PubMed]

55. Lei, T.; Guo, N.; Liu, J.Q.; Tan, M.H.; Li, Y.F. Vitrification of in vitro matured oocytes: Effects on meiotic spindle configuration and mitochondrial function. Int. J. Clin. Exp. Pathol. 2014, 7, 1159-1165. [PubMed]

56. Martinez-Burgos, M.; Herrero, L.; Megias, D.; Salvanes, R.; Montoya, M.C.; Cobo, A.C.; Garcia-Velasco, J.A. Vitrification versus slow freezing of oocytes: Effects on morphologic appearance, meiotic spindle configuration, and DNA damage. Fertil. Steril. 2011, 95, 374-377. [CrossRef] [PubMed]

57. Dominguez, F.; Castello, D.; Remohi, J.; Simon, C.; Cobo, A. Effect of vitrification on human oocytes: A metabolic profiling study. Fertil. Steril. 2013, 99, 565-572. [CrossRef]

58. Ohnishi, N.; Kodania, H.; Ando, S.; Komamine, A. Synthesis of protein and mRNA is necessary for transition of suspension-cultured Catharanthus roseus cells from the G1 to the S phase of the cell cycle. Physiol. Plant. 1990, 80, 95-101. [CrossRef]

59. Deckbar, D.; Stiff, T.; Koch, B.; Reis, C.; Löbrich, M.; Jeggo, P.A. The limitations of the G1-S checkpoint. Cancer Res. 2010, 70, 4412-4421. [CrossRef]

60. Khan, F.; Khan, I.; Farooqui, A.; Ansari, I.A. Carvacrol Induces Reactive Oxygen Species (ROS)-mediated Apoptosis Along with Cell Cycle Arrest at G0/G1 in Human Prostate Cancer Cells. Nutr. Cancer 2017, 69, 1075-1087. [CrossRef]

61. Chung, Y.M.; Sun, M.C.; Kim, Y.H.; Kim, J.S.; Yoo, Y.D. A novel gene, Chemp-1, produces ROS and induces cell-cycle arrest at G1. Cancer Res. 2004, 64.

62. Cos, S.; Blask, D.E.; Lemus-Wilson, A.; Hill, A.B. Effects of melatonin on the cell cycle kinetics and "estrogen-rescue" of MCF-7 human breast cancer cells in culture. J. Pineal Res. 1991, 10, 36-42. [CrossRef] [PubMed]

63. Ookawa, K.; Tsuchida, S.; Kohno, T.; Yokota, J. Alterations in expression of E2F-1 and E2F-responsive genes by RB, p53 and p21(Sid1/WAF1/Cip1) expression. FEBS Lett. 2001, 500, 25-30. [CrossRef] 
64. Radhakrishnan, S.K.; Feliciano, C.S.; Najmabadi, F.; Haegebarth, A.; Kandel, E.S.; Tyner, A.L.; Gartel, A.L. Constitutive expression of E2F-1 leads to p21-dependent cell cycle arrest in S I [thinsp] | phase of the cell cycle. Oncogene 2004, 23, 4173-4176. [CrossRef] [PubMed]

65. Qin, X.Q.; Livingston, D.M.; Ewen, M.; Sellers, W.R.; Arany, Z.; Kaelin, W.G., Jr. The transcription factor E2F-1 is a downstream target of RB action. Mol. Cell. Biol. 1995, 15, 742-755. [CrossRef] [PubMed]

66. Amoushahi, M.; Salehnia, M.; Mowla, S.J. Vitrification of Mouse MII Oocyte Decreases the Mitochondrial DNA Copy Number, TFAM Gene Expression and Mitochondrial Enzyme Activity. J. Reprod. Infertil. 2017, 18, 343-351. [PubMed]

67. Voehringer, D.W. BCL-2 and glutathione: Alterations in cellular redox state that regulate apoptosis sensitivity. Free Radic. Biol. Med. 1999, 27, 945-950. [CrossRef]

68. Jiang, S.; Moriarty-Craige, S.E.; Orr, M.; Cai, J.; Sternberg, P., Jr.; Jones, D.P. Oxidant-induced apoptosis in human retinal pigment epithelial cells: Dependence on extracellular redox state. Investig. Ophthalmol. Vis. Sci. 2005, 46, 1054-1061. [CrossRef]

69. Lee, E.K.; Kim, J.A.; Kim, J.S.; Park, S.J.; Heo, K.; Yang, K.M.; Son, T.G. Activation of de novo GSH synthesis pathway in mouse spleen after long term low-dose gamma-ray irradiation. Free Radic. Res. 2013, 47, 89-94. [CrossRef]

70. He, B.; Yin, C.; Gong, Y.; Liu, J.; Guo, H.; Zhao, R. Melatonin-induced increase of lipid droplets accumulation and in vitro maturation in porcine oocytes is mediated by mitochondrial quiescence. J. Cell. Physiol. 2018, 233, 302-312. [CrossRef]

71. Fair, T.; Hulshof, S.C.; Hyttel, P.; Greve, T.; Boland, M. Oocyte ultrastructure in bovine primordial to early tertiary follicles. Anat. Embryol. 1997, 195, 327-336. [CrossRef] [PubMed]

72. Favetta, L.A.; St John, E.J.; King, W.A.; Betts, D.H. High levels of p66shc and intracellular ROS in permanently arrested early embryos. Free Radic. Biol. Med. 2007, 42, 1201-1210. [CrossRef] [PubMed]

73. Gao, C.; Han, H.B.; Tian, X.Z.; Tan, D.X.; Wang, L.; Zhou, G.B.; Zhu, S.E.; Liu, G.S. Melatonin promotes embryonic development and reduces reactive oxygen species in vitrified mouse 2-cell embryos. J. Pineal Res. 2012, 52, 305-311. [CrossRef] [PubMed]

74. Jiang, L.; Hickman, J.H.; Wang, S.J.; Gu, W. Dynamic roles of p53-mediated metabolic activities in ROS-induced stress responses. Cell Cycle 2015, 14, 2881-2885. [CrossRef] [PubMed]

75. Whittingham, D.G. Culture of mouse ova. J. Reprod. Fertil. Suppl. 1971, 14, 7-21. [PubMed]

76. Vajta, G.; Holm, P.; Kuwayama, M.; Booth, P.J.; Jacobsen, H.; Greve, T.; Callesen, H. Open Pulled Straw (OPS) vitrification: A new way to reduce cryoinjuries of bovine ova and embryos. Mol. Reprod. Dev. 1998, 51, 53-58. [CrossRef]

77. Yan, C.L.; Fu, X.W.; Zhou, G.B.; Zhao, X.M.; Suo, L.; Zhu, S.E. Mitochondrial behaviors in the vitrified mouse oocyte and its parthenogenetic embryo: Effect of Taxol pretreatment and relationship to competence. Fertil. Steril. 2010, 93, 959-966. [CrossRef]

78. Quinn, P.; Kerin, J.F.; Warnes, G.M. Improved pregnancy rate in human in vitro fertilization with the use of a medium based on the composition of human tubal fluid. Fertil. Steril. 1985, 44, 493-498. [CrossRef]

79. Carbone, M.C.; Tatone, C. Alterations in the protein kinase $\mathrm{C}$ signaling activated by a parthenogenetic agent in oocytes from reproductively old mice. Mol. Reprod. Dev. 2009, 76, 122-131. [CrossRef]

80. Ho, Y.; Wigglesworth, K.; Eppig, J.J.; Schultz, R.M. Preimplantation development of mouse embryos in KSOM: Augmentation by amino acids and analysis of gene expression. Mol. Reprod. Dev. 1995, 41, 232-238. [CrossRef]

81. Xiao, J.Y.; Liu, C.; Sun, X.H.; Yu, B.Z. Cdc25b subcellular localization influences one-cell stage mouse embryos. Chinese J. Biochem. Mol. Biol. 2013, 29, 33-41. [CrossRef]

82. Wu, G.Q.; Jia, B.Y.; Li, J.J.; Fu, X.W.; Zhou, G.B.; Hou, Y.P.; Zhu, S.E. L-carnitine enhances oocyte maturation and development of parthenogenetic embryos in pigs. Theriogenology 2011, 76, 785-793. [CrossRef] [PubMed]

83. Livak, K.J.; Schmittgen, T.D. Analysis of relative gene expression data using real-time quantitative PCR and the 2(-Delta Delta C(T)) Method. Methods 2001, 25, 402-408. [CrossRef] [PubMed]

(C) 2018 by the authors. Licensee MDPI, Basel, Switzerland. This article is an open access article distributed under the terms and conditions of the Creative Commons Attribution (CC BY) license (http://creativecommons.org/licenses/by/4.0/). 